\title{
Dynamic changes of nutrition in litchi foliar and effects of potassium-nitrogen fertilization ratio
}

\author{
B.M. Yang ${ }^{1 *}$, L.X. $\mathrm{Yao}^{2}$, G.L. Li ${ }^{1}$, Z.H. $\mathrm{He}^{1}$ and C.M. Zhou \\ ${ }^{1}$ Institute of Agricultural Resources and Environment, Guangdong Academy of Agricultural Sciences, Key \\ Laboratory of Plant Nutrition and Fertilizer in South Region, Ministry of Agriculture, Guangdong Key \\ Laboratory of Nutrient Cycling and Farmland Conservation, ${ }^{2}$ College of Resources and Environmental \\ Science, South China Agricultural University, 510640, Guangzhou,P.R. China. *Corresponding author: \\ yangbaomei163@163.com
}

\begin{abstract}
Field experiments were conducted to determine the annual dynamic changes of element contents in litchi leaves and the effects of the potassium and nitrogen ratio $\left(\mathrm{K}_{2} \mathrm{O} / \mathrm{N}\right.$ ratios: $0.6,0.8,1.0,1.2$, and 1.4) on the yield and planting benefits of litchi. The cultivar 'Feizixiao' litchi planted in a typical acidic upland orchard was used as a subject. The following results were obtained. (1) The elemental contents of litchi leaves significantly varied during the different developmental stages. Throughout the developmental period, the elemental contents in litchi leaves were in the descending order of $\mathrm{N}>\mathrm{K}>\mathrm{Ca}>\mathrm{Mg}>\mathrm{P}>\mathrm{S}>\mathrm{B}>\mathrm{Zn}>$ Mo. The $\mathrm{K}$ content showed a highly significant negative correlation with the $\mathrm{Ca}$ and $\mathrm{Mg}$ contents and significant negative correlation with the $\mathrm{Zn}$ content. The $\mathrm{Ca}, \mathrm{Mg}$, and $\mathrm{Zn}$ contents exhibited significantly positive correlation with each other. The $\mathrm{N}$ content was significantly negatively correlated with the $\mathrm{S}$ and $\mathrm{B}$ contents in leaves, and the $\mathrm{S}$ and $\mathrm{B}$ contents showed significant positive correlation with each other. The $\mathrm{P}$ content exhibited significant negative correlation with $\mathrm{Ca}$ and $\mathrm{Si}$, whereas $\mathrm{Ca}$ and $\mathrm{Si}$ were significantly positively correlated with each other. (2) Under the same $\mathrm{N}$ application conditions, the yield and planting benefits of litchi initially increased and then subsequently decreased with increasing $\mathrm{K}_{2} \mathrm{O} / \mathrm{N}$ ratio. litchi had the highest yield and plant benefit when the ratio of $\mathrm{K}_{2} \mathrm{O}$ to $\mathrm{N}$ ranged from 1.0 to 1.2. Thus, this ratio is recommended for the main litchi production areas in China.
\end{abstract}

Keywords: Litchi, Feizixiao, mineral elements, $\mathrm{K}_{2} \mathrm{O} / \mathrm{N}$ ratio, yield

\section{Introduction}

Litchi (Litchi chinensis Sonn.) is a plant species belonging to the Sapindaceae family. China is the largest litchi-producing country in the world, where the litchi growing area and production accounts for
$80 \%$ of the global output because of the country's natural conditions. However, litchi's unit yields are generally low and unstable (Xu et al., 2010). Unreasonable litchi orchard fertilization (Yao et 
al., 2009), generally low $\mathrm{N}$ and $\mathrm{K}$ soil contents ( $\mathrm{Li}$ et al., 2011), and litchi trees with low $\mathrm{K}$ nutrition (Yao et al., 2009) are some of the most significant reasons for these low and unstable unit yields. Analysis and diagnosis of foliar nutrients have been widely applied in international fruit tree nutrition research and production (Jiang et al., 2005), and fruitful achievements are made in the studies on many fruit trees such as jujube (Zhang et al., 2012), apple (Nachtigal and Dechen, 2007), navel orange (Zhou et al., 2004), grape (Jiang et al., 2005), plum (Li et al., 2007), grapefruit (He et al., 2003), orange (Torres et al., 2010), mango (Raghupathi et al., 2004), pineapple (Agbangba et al., 2011). In addition, there are some reports on litchi foliar mineral nutrition dynamics in Australia, South Africa, and the United States (Menzel et al., 1992; Menzel and Simpson 1987), which are rarely seen in China. According to previous studies, the $\mathrm{K}$ and $\mathrm{N}$ contents in leaf are closely related to plant status, flowering, yield, nutrition and growth of plant (Reyes, 2000), meanwhile, $\mathrm{N}$ has high degree of interaction with K (Bussi et al., 1992), and fruit yield and quality are closely related to K-N balance (Egea et al., 1992). There is big difference in the use rate, time and frequency of $\mathrm{K}$ and $\mathrm{N}$ in different countries' litchi production (Menzel et al., 1992; Menzel and Simpson 1987) perhaps for varied litchi varieties, climate characteristics, soil conditions, cultivation and management measures and yield levels. So, it is difficult to summarize an application method of potassium-nitrogen fertilizer that has wider reference significance for litchi production. Therefore, studies on fertilization using $\mathrm{K}$ and $\mathrm{N}$ with different proportions were conducted as researchers focused on $\mathrm{K}$ and $\mathrm{N}$ as the main nutritional elements needed for litchi normal growth (Yao et al., 2009). Periodic leaf nutrition analysis was also carried out. The litchi yield was used as the standard for research to obtain the optimal $\mathrm{K}$ and $\mathrm{N}$ proportion for litchi and to provide theoretical basis and practical guidance for litchi fertilization management, nutritional regulation, and increase of litchi fertilization effects.

\section{Materials and Methods}

Field experiments were carried out in Shouwang orchard $\left(23.0290^{\circ} \mathrm{N}, 114.5551^{\circ} \mathrm{E}\right)$ located in Huidong County, Guangdong Province, from June 2009 to June 2012, during three fruit harvest seasons.

\subsection{Litchi variety and soil used}

The litchi cultivar used was 'Feizixiao' which was planted in 1995 with a spacing of $5 \mathrm{~m} \times 6 \mathrm{~m}(330$ plants per hectare) in the slope terraces of Shouwang orchard. The soil in this orchard was the lateritic red soil type, which is typical in Southern China. Soil samples were collected at $0 \mathrm{~cm}$ to $60 \mathrm{~cm}$ soil depth prior to the experiment. The soil contained OM (8.6 $\mathrm{g} \mathrm{kg}^{-1}$ ), alkali-hydrolyzable $\mathrm{N}\left(44.1 \mathrm{mg} \mathrm{kg}^{-1}\right), \mathrm{NH}_{4}{ }^{+}-\mathrm{N}$ (2.0 $\left.\mathrm{mg} \mathrm{kg}^{-1}\right)$, and $\mathrm{NO}_{3}^{-}-\mathrm{N}\left(1.2 \mathrm{mg} \mathrm{kg}^{-1}\right)$ and contained $\mathrm{P}$ (7.9 $\left.\mathrm{mg} \mathrm{kg}^{-1}\right), \mathrm{K}$ (73.3 $\left.\mathrm{mg} \mathrm{kg}^{-1}\right), \mathrm{Ca}\left(866.4 \mathrm{mg} \mathrm{kg}^{-1}\right)$, $\mathrm{Mg}\left(66.1 \mathrm{mg} \mathrm{kg}^{-1}\right), \mathrm{Zn}\left(0.45 \mathrm{mg} \mathrm{kg}^{-1}\right), \mathrm{B}(0.16 \mathrm{mg} \mathrm{kg}$ $\left.{ }^{1}\right)$, and Mo $\left(0.08 \mathrm{mg} \mathrm{kg}^{-1}\right)$. In addition, the soil had a $\mathrm{pH}$ value of 4.61 and a loamy clay texture. Thus, the soil was deficient in $\mathrm{OM}$; abundant in $\mathrm{N}, \mathrm{Zn}, \mathrm{B}$, and $\mathrm{Mo}$; and has low to moderate $\mathrm{P}, \mathrm{K}$, and $\mathrm{Mg}$ contents.

\subsection{Experimental treatments}

The field experiments were conducted using five treatments, more specifically, five fertilizers with specific $\mathrm{K}_{2} \mathrm{O} / \mathrm{N}$ ratios. The $\mathrm{K}_{2} \mathrm{O} / \mathrm{N}$ ratios of $0.6,0.8$, 1.0, 1.2, and 1.4 were set and denoted as $\mathrm{K}_{0.6} \mathrm{~N}, \mathrm{~K}_{0.8} \mathrm{~N}$, $\mathrm{K}_{1.0} \mathrm{~N}, \mathrm{~K}_{1.2} \mathrm{~N}$, and $\mathrm{K}_{1.4} \mathrm{~N}$. Each treatment was conducted in three replicates with five trees in each plot.

The usage rates of $\mathrm{N}$ in litchi were 198, 129, and 165 $\mathrm{kg} \mathrm{ha}^{-1}$ in 2009-2010, 2010-2011, and 2011-2012, 
respectively. $\mathrm{K}_{2} \mathrm{O}$ was applied at rates that were 0.6 , $0.8,1.0,1.2$, and 1.4 times that of $\mathrm{N}$ in each growth year. In addition, the same amounts of $\mathrm{P}, \mathrm{Ca}, \mathrm{Mg}, \mathrm{Zn}$, $\mathrm{B}$, and Mo were added in all treatments in the same year, to prevent nutrient deficiencies other than that of $\mathrm{N}$ and $\mathrm{K}$.

Between 2009 and 2010, the litchi had been applied four times when were after fruit harvest

(application amount of nitrogen and phosphate fertilizer accounting for $30 \%$ of the total fertilizing amount of the period; potassium, calcium and magnesium fertilizer accounting for $20 \%$ and heptahydrate, sodium borate and ammonium molybdate accounting for $50 \%$ ), before blossoming ( $20 \%$ of nitrogen, phosphate, potassium, calcium and magnesium fertilizer and $50 \%$ of heptahydrate, sodium borate and ammonium molybdate), at flower fading ( $20 \%$ of nitrogen, phosphate, potassium, calcium and magnesium fertilizer) and at fruit developing stages (30\% of nitrogen and phosphate fertilizer and $40 \%$ of potassium, calcium and magnesium fertilizer).

Between 2010 and 2011, the litchi had been applied two times when were after fruit harvest (application amount of nitrogen and phosphate accounting for $62 \%$ of the total fertilizing amount of the period, and potassium, calcium and magnesium fertilizer accounting for 55\%) and at flower fading (38\% of nitrogen and phosphate fertilizer and $45 \%$ of potassium, calcium and magnesium fertilizer).

Between 2011 and 2012, the litchi had been applied four times when were after fruit harvest (application amount of nitrogen and phosphate fertilizer accounting for $45 \%$ of the total fertilizing amount of the period; potassium and magnesium fertilizer accounting for $30 \%$ and phosphate fertilizer, heptahydrate, sodium borate and ammonium molybdate accounting for $100 \%$ ), before blossoming ( $10 \%$ of nitrogen, potassium and magnesium fertilizer and $100 \%$ of calcium fertilizer), at flower fading $(20 \%$ of nitrogen, potassium and magnesium fertilizer) and at fruit developing stages (the application amount of nitrogen fertilizer accounts for $25 \%$ of the total fertilizing amount of the period; $40 \%$ of potassium and magnesium fertilizer).

Urea, super phosphate, potassium chloride, lime, magnesium sulfate, zinc sulfate, borax, and ammonium molybdate were used in this experiment.

\subsection{Sampling and mineral element measurement}

During litchi maturation period, the fruits were weighed based on the harvest per plot. The paid-in harvest amount and yield per hectare were calculated. The harvest periods were from May 31 to June 8 in 2010, June 10 to June 20 in 2011, and May 28 to June 15 in 2012.

Litchi leaf samples were collected during the different growth phases, more specifically on the following dates: June 20 (the day after fruit picking), September 5, October 15, November 27, and December 23 in 2011; and February 28, March 28, April 24, and May 23 (5 days before fruit picking) in 2012. Newly matured litchi leaves from the autumn shoots (second or third leaf pairs of second compound leaves) were collected from the south, south-west, north-west, north, north-east, east, and south-east directions of the litchi canopy. A total of 32 to 40 leaves were obtained from each strain to collect a mixed sample for each part. After washing, steaming, and drying, the dry weights of the leaves were recorded, which were then used for mineral content analysis. The $\mathrm{N}$ content of the leaves was determined by $\mathrm{H}_{2} \mathrm{SO}_{4}-\mathrm{H}_{2} \mathrm{O}_{2}$ heating digestion and steaming. The $\mathrm{P}$ content of the leaves was determined by $\mathrm{H}_{2} \mathrm{SO}_{4}-\mathrm{H}_{2} \mathrm{O}_{2}$ heating digestion and $\mathrm{Mo}-\mathrm{Sb}-\mathrm{Vc}$ colorimetry. The $\mathrm{K}$ content of the leaves was determined by $\mathrm{H}_{2} \mathrm{SO}_{4}-\mathrm{H}_{2} \mathrm{O}_{2}$ heating digestion and flame photometry, whereas the $\mathrm{Ca}, \mathrm{Mg}$, and $\mathrm{Zn}$ contents of the leaves were determined by $\mathrm{HNO}_{3}-\mathrm{HClO}_{4}$ heating digestion and atomic absorption spectrophotometry. The 
S content of the leaves was determined by $\mathrm{HNO}_{3}-\mathrm{HClO}_{4}$ heating digestion and turbidimetry. The $\mathrm{B}$ content of the leaves was determined by curcumin colorimetry. The Mo content of the leaves was determined by polarography. The assays of mineral elements were carried out according to Lu et al (2000). Whereas, the Si content of the leaves was determined based on standard assays (LY/T 1270-1999). All items were used to control and test the quality with standard material GBW07603.

\subsection{Yield stability calculation}

Crop yield stability is an important indicator in judging the quality of farmland ecosystems (Men et al., 2008). Litchi production stability was measured with two indicators, namely, the yield stability coefficient (SYI) and coefficient variation (CV). The formula for SYI calculation is given as follows (Men et al., 2008) : $\quad S Y I=\frac{\bar{Y}-\sigma}{Y \max }$

where $\bar{Y}$ is the average annual yield per area $\left(\mathrm{kg} \mathrm{ha}^{-1}\right)$; $\sigma(\mathrm{Sd})$ is the standard deviation $\left(\mathrm{kg} \mathrm{ha}^{-1}\right)$; and $Y_{\max }$ is the maximum yield from all years $\left(\mathrm{kg} \mathrm{ha}^{-1}\right)$. SYI can be any value between 0 and 1 . A high standard deviation results in a SYI value closer to 0 , and a high SYI value means stable crop yields (Sharma et al., 2005). CV can also be used to measure the degree of variation of the same species between the average crop yields at different years (Hu et al., 1993). The formula for this calculation is $C V=S / \bar{X}$, where $S$ is the standard deviation $\left(\mathrm{kg} \mathrm{ha}^{-1}\right)$, and $\bar{X}$ is the average annual yield $\left(\mathrm{kg} \mathrm{ha}^{-1}\right)$. A high $\mathrm{CV}$ value indicates low stability. Thus, the differences between various yield stability treatments can be compared.

\subsection{Statistical analysis}

All experiments were performed in triplicates $(n=3)$. ANOVA test (SAS/STAT software) was used to compare the mean values of each treatment. Significant differences between the means of the parameters were determined using the Duncan's multiple range test $(p<0.05)$.

\section{Results}

\subsection{Changes of nutrient contents in leaves}

3.1.1. Changes of nitrogen, potassium, calcium and magnesium content in leaves

In each growth period, the $\mathrm{N}, \mathrm{K}, \mathrm{Ca}$, and $\mathrm{Mg}$ contents were high in the litchi leaf samples and followed the order $\mathrm{N}>\mathrm{K}>\mathrm{Ca}>\mathrm{Mg}$ (Figure 1). The $\mathrm{N}$ content of the leaves initially remained at a constantly high level, which was significantly higher in the flower bud differentiation period than in other growth periods. Subsequently, the $\mathrm{N}$ content decreased with the growth of panicle and blossom as the leaf $\mathrm{N}$ content mainly transferred toward the reproductive growth center. The $\mathrm{K}$ content of the leaves remained at a high in autumn shoot mature period. However, in the flower bud differentiation to early fruit expansion period, the $\mathrm{K}$ content drastically decreased, in which the average leaf $\mathrm{K}$ content in April and November was only $65.0 \%$. This decrease in $\mathrm{K}$ content may be caused by two possible reasons. First, the $\mathrm{K}$ content may have been transferred toward the reproduction and growth centers. However, the transfer of the $\mathrm{K}$ content to the spring shoots and leaves could not be excluded after spring. In the late fruit expansion period, the leaf $\mathrm{K}$ content increases. In June, after fruit picking, the leaf $\mathrm{K}$ content rapidly decreases to a minimal level. The mechanisms involved in this decrease still need further research. As the litchi grows, the leaf $\mathrm{Ca}$ content experience a declining-increasing-declining development, but eventually reaches a certain maximum value after fruit picking and a second maximum value during 
blossoming and fruit setting. The $\mathrm{K}$ and $\mathrm{Ca}$ contents showed significant increase and decrease, which were nearly the same during the post-fruit picking and fruit expansion periods. This observation indicates that the post-fruit picking and expansion periods are the critical stages for litchi $\mathrm{K}$ and $\mathrm{Ca}$ nutrition. The $\mathrm{Mg}$ content of leaf remained stable and reached its maximum level after the fruit-picking period.

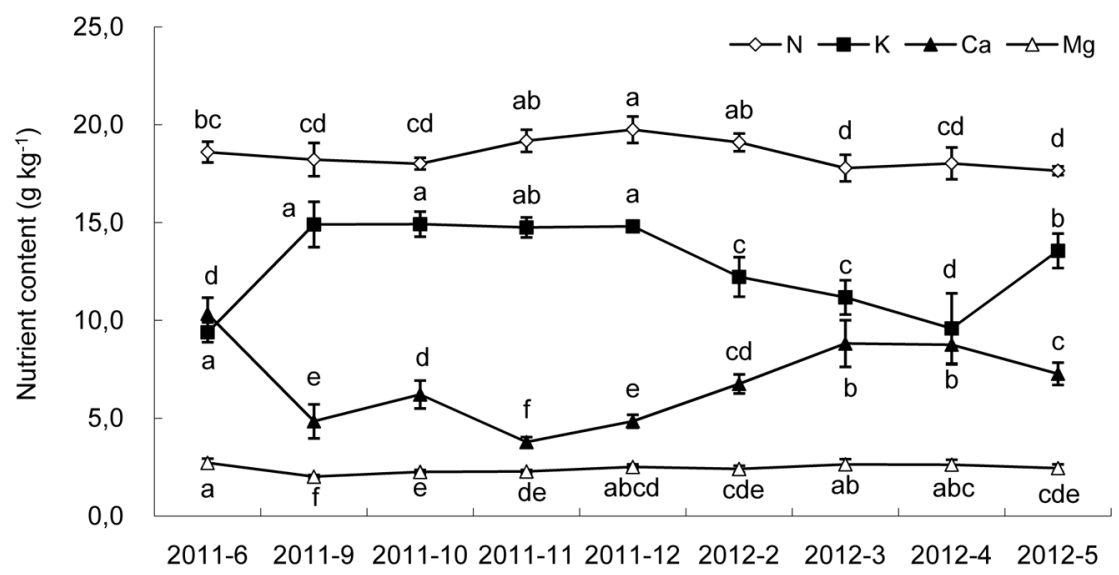

Figure 1. Changes of N, K, Ca, Mg content in leaves of the Litchi. June 2011: post-harvest; September 2011 to late November 2011: autumn shoot maturation period; late November 2011 to February 2012: flower bud differentiation; March 2012: bloom; April 2012: early fruit enlargement; May 2012: late fruit enlargement.

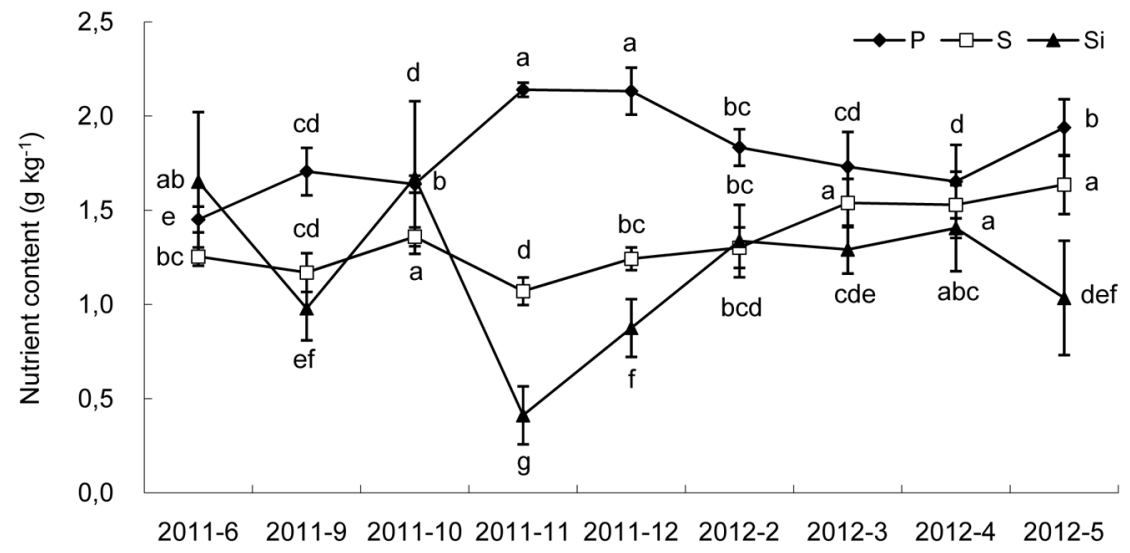

Figure 2. Changes of P, S, Si content in leaves of the Litchi. June 2011: post-harvest; September 2011 to late November 2011: autumn shoot maturation period; late November 2011 to February 2012: flower bud differentiation; March 2012: bloom; April 2012: early fruit enlargement; May 2012: late fruit enlargement. 
3.1.2. Changes of phosphorus, sulfur, and silicon contents in leaves

Figure 2 shows that throughout the growth period, the leaf $\mathrm{P}$ content was higher than that of S. The leaf $\mathrm{P}$ content increased after the fruit picking period to the early flower bud differentiation period and then reached the maximum level in the early flower bud differentiation period. Subsequently, the $\mathrm{P}$ content decreased in the blossoming and fruit setting periods. In April, the average leaf $\mathrm{P}$ content was only $77.1 \%$ of that in November. The cause of this phenomenon is similar to that of the decrease in leaf $\mathrm{K}$ content. In the subsequent fruit expansion period to before the fruit picking period, the leaf $\mathrm{P}$ content significantly increased. However, the $\mathrm{P}$ content after the fruit picking period decreased to a minimum value, which is similar with the observations for the leaf $\mathrm{K}$ content. The growth and decline of the $\mathrm{P}$ and $\mathrm{S}$ contents have a significant relationship. In addition, their contents after the fruit picking and fruit enlargement periods were close, indicating that the fruit picking and enlargement periods are both critical stages for the litchi $\mathrm{P}$ and $\mathrm{S}$ nutrients. Moreover, the annual volatile leaf Si content was high and had an overall decreasing-increasing trend. The leaf Si content in the flower bud differentiation period rapidly increased.

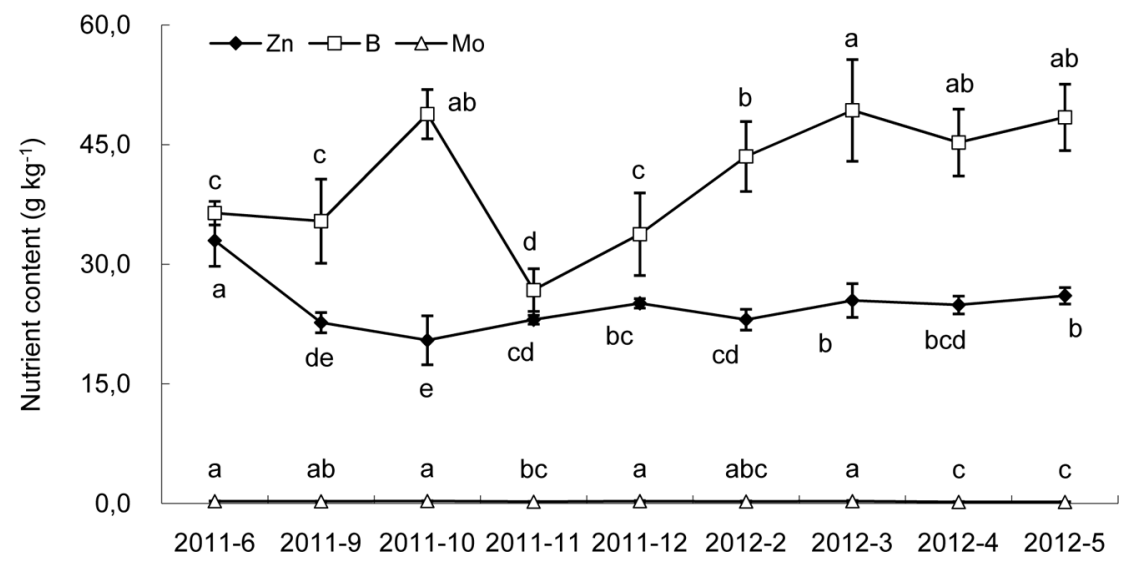

Figure 3. Changes of Zn, B, Mo content in leaves of the Litchi. June 2011: post-harvest; September 2011 to late November 2011: autumn shoot maturation period; late November 2011 to February 2012: flower bud differentiation; March 2012: bloom; April 2012: early fruit enlargement; May 2012: late fruit enlargement.

3.1.3. Changes of boron, zinc and molybdenum content in leaves

Figure 3 shows the changing trends of leaf $\mathrm{B}, \mathrm{Zn}$, and Mo contents in various periods. These nutrients showed the following decreasing order: $\mathrm{B}>\mathrm{Zn}>\mathrm{Mo}$. In the autumn shoot maturity period, the $\mathrm{B}$ content showed an increasing-decreasing trend. In the flower bud differentiation period to the blossoming period, the leaf B content rapidly increased. Compared with that in November, the leaf B content in December, February, and March increased with varying degrees. In the blossoming period to the fruit expansion period, the B content decreased, suggesting that the 
B nutrient needs to be consumed before further litchi development. B fertilization aids in the improvement of litchi fruit set percentage as well as fruit development. In the fruit expansion period to the prefruit picking period, the leaf $\mathrm{B}$ content increased again. In the nutrition growth period, the $\mathrm{Zn}$ content rapidly decreased with the development of reproduction period. In September and October, the average $\mathrm{Zn}$ content was $2 / 3$ of that in June, indicating that $\mathrm{Zn}$ was highly consumed in this period. The $\mathrm{Zn}$ content remained at a stable level during the reproduction and growth stages. The leaf Mo content was $0.18 \mathrm{mg} \mathrm{kg}^{-1}$ to $0.30 \mathrm{mg} \mathrm{kg}^{-1}$ throughout the reproduction period and was stable at low levels.

\subsubsection{Mutual relationship between litchi leaf nutrients}

Various mineral nutrients have a certain balance in healthy growing plants. However, differences exist in the absorption and carrying abilities of mineral nutrients during different litchi developing periods, wherein the balances vary with the growth and development of plants. The annual dynamic changing proportion of litchi nutrient content (N:P:K:Ca:Mg:S:Si) was 1:0.08-0.11:0.50-0.83:0.200.56:0.11-0.15:0.06-0.09:0.02-0.09. The relevance of the various degrees of litchi leaves is shown in different nutrient elements (Table 1). The leaf $\mathrm{N}$ content was negatively correlated with the leaf $\mathrm{S}$ and $\mathrm{B}$ contents, which had significantly positive correlation with each other. The $\mathrm{P}$ content exhibited significantly negative correlation with $\mathrm{Ca}$ and $\mathrm{Si}$, which had significantly positive correlation with each other. The $\mathrm{K}$ content had a significantly negative correlation with the $\mathrm{Zn}, \mathrm{Ca}$, and $\mathrm{Mg}$ contents. The $\mathrm{Ca}$, $\mathrm{Mg}$, and $\mathrm{Zn}$ contents exhibited significantly positive correlation with each other. The results indicate that antagonistic effects exist among $\mathrm{K}, \mathrm{Ca}, \mathrm{Mg}$, and $\mathrm{Zn}$ in litchi leaves, whereas synergetic effects exist among $\mathrm{Ca}, \mathrm{Mg}$, and $\mathrm{Zn}$. Antagonistic effects exist among N, $\mathrm{S}$, and $\mathrm{B}$ in litchi leaves, whereas synergetic effects exist between $\mathrm{S}$ and B. Furthermore, antagonistic effects exist among $\mathrm{P}, \mathrm{Ca}$, and $\mathrm{Si}$ in litchi leaves, whereas synergetic effects exist between $\mathrm{Ca}$ and $\mathrm{Si}$.

Table 1. The correlation between the different elements in leaves of the Litchi

\begin{tabular}{ccccccccccc}
\hline Element & $\mathrm{N}$ & $\mathrm{P}$ & $\mathrm{K}$ & $\mathrm{Ca}$ & $\mathrm{Mg}$ & $\mathrm{S}$ & $\mathrm{Si}$ & $\mathrm{Zn}$ & $\mathrm{B}$ & $\mathrm{Mo}$ \\
\hline $\mathrm{N}$ & 1.0000 & & & & & & & & \\
$\mathrm{P}$ & 0.5477 & 1.0000 & & & & & & & \\
$\mathrm{~K}$ & 0.2700 & 0.6289 & 1.0000 & & & & & & & \\
$\mathrm{Ca}$ & -0.4875 & $-0.7487^{*}$ & $-0.9130^{* * *}$ & 1.0000 & & & & & & \\
$\mathrm{Mg}$ & -0.0349 & -0.2425 & $-0.8011^{* *}$ & $0.7833^{*}$ & 1.0000 & & & & & \\
$\mathrm{~S}$ & $-0.7243^{*}$ & -0.2363 & -0.4084 & 0.5861 & 0.4680 & 1.0000 & & & & \\
$\mathrm{Si}$ & -0.4331 & $-0.8659^{*}$ & -0.5679 & $0.7529^{*}$ & 0.3868 & 0.4134 & 1.0000 & & & \\
$\mathrm{Zn}$ & 0.0048 & -0.3710 & $-0.6790^{*}$ & $0.6968^{*}$ & $0.7244^{*}$ & 0.1083 & 0.2671 & 1.0000 & & \\
$\mathrm{~B}$ & $-0.7385^{*}$ & -0.4348 & -0.3043 & 0.5429 & 0.2630 & $0.8765^{* *}$ & 0.6618 & -0.1149 & 1.0000 & \\
$\mathrm{Mo}$ & 0.1975 & -0.2837 & 0.2017 & -0.0056 & -0.0783 & -0.3418 & 0.3776 & 0.0307 & -0.0212 & 1.0000 \\
\hline
\end{tabular}

Notes: Values with * are significantly different by the CORR Test $(\mathrm{P}<0.05)$, and values with ** are significantly different by the CORR Test $(\mathrm{P}<0.01)$. 
Table 2. Agronomic characteristics of litchi fruits in various treatments

\begin{tabular}{|c|c|c|c|c|c|}
\hline \multirow[b]{2}{*}{ Treatment } & \multirow{2}{*}{$\begin{array}{c}2010 \\
\text { Weight per } \\
\text { fruit }(\mathrm{g})\end{array}$} & \multicolumn{3}{|c|}{2011} & \multirow{2}{*}{$\begin{array}{c}2012 \\
\text { Weight per fruit } \\
\text { (g) }\end{array}$} \\
\hline & & Length(mm) & Width (mm) & Height (mm) & \\
\hline $\mathrm{K}_{0.6} \mathrm{~N}$ & $30.6 \pm 1.8 \mathrm{a}$ & $36.5 \pm 1.0 \mathrm{a}$ & $35.4 \pm 0.6 \mathrm{a}$ & $33.4 \pm 0.4 \mathrm{a}$ & $27.1 \pm 1.5 \mathrm{a}$ \\
\hline $\mathrm{K}_{0.8} \mathrm{~N}$ & $31.8 \pm 1.0 \mathrm{a}$ & $37.6 \pm 0.5 \mathrm{a}$ & $36.6 \pm 0.9 \mathrm{a}$ & $34.2 \pm 0.9 \mathrm{a}$ & $28.2 \pm 2.4 \mathrm{a}$ \\
\hline $\mathrm{K}_{1.0} \mathrm{~N}$ & $31.7 \pm 0.6 \mathrm{a}$ & $37.5 \pm 0.2 \mathrm{a}$ & $37.2 \pm 0.4 \mathrm{a}$ & $35.0 \pm 0.3 \mathrm{a}$ & $29.3 \pm 0.8 \mathrm{a}$ \\
\hline $\mathrm{K}_{1.2} \mathrm{~N}$ & $33.0 \pm 0.3 \mathrm{a}$ & $37.1 \pm 0.6 \mathrm{a}$ & $36.1 \pm 0.7 \mathrm{a}$ & $34.3 \pm 0.6 \mathrm{a}$ & $30.2 \pm 0.5 \mathrm{a}$ \\
\hline $\mathrm{K}_{1.4} \mathrm{~N}$ & $30.0 \pm 2.2 \mathrm{a}$ & $36.9 \pm 1.1 \mathrm{a}$ & $35.3 \pm 1.6 \mathrm{a}$ & $33.5 \pm 1.3 \mathrm{a}$ & $27.7 \pm 1.3 \mathrm{a}$ \\
\hline
\end{tabular}

Table 3. Average yield and yield stability of litchi in different fertilizer treatments

\begin{tabular}{ccccc}
\hline Treatment & $\begin{array}{c}\text { Average yield } \\
\left(\mathrm{kg} \mathrm{ha}^{-1}\right)\end{array}$ & $\begin{array}{c}\text { Maximum yield } \\
\left(\mathrm{kg} \mathrm{ha}^{-1}\right)\end{array}$ & $\mathrm{CV}(\%)$ & SYI \\
\hline $\mathrm{K}_{0.6} \mathrm{~N}$ & 6905 & 9585 & 46.4 & 0.39 \\
$\mathrm{~K}_{0.8} \mathrm{~N}$ & 7770 & 9990 & 42.8 & 0.44 \\
$\mathrm{~K}_{1.0} \mathrm{~N}$ & 8670 & 10875 & 43.3 & 0.45 \\
$\mathrm{~K}_{1.2} \mathrm{~N}$ & 9455 & 12630 & 35.0 & 0.49 \\
$\mathrm{~K}_{1.4} \mathrm{~N}$ & 8385 & 11190 & 42.6 & 0.43 \\
\hline
\end{tabular}

\subsection{Fruit agronomic characteristics}

Table 2 shows that the litchi fruit weight, as well as the length, width, and height, initially increased with different treatments but subsequently decreased with increasing $\mathrm{K}_{2} \mathrm{O} / \mathrm{N}$ proportion and then reached the maximum level with $\mathrm{K}_{1.0} \mathrm{~N}$ or $\mathrm{K}_{1.2} \mathrm{~N}$ treatment. In addition, with the extension of the test time, variation in the litchi fruit weight with different treatments increased. These results indicated that the litchi fruit size trended towards to enlarger after combined application of appropriate $\mathrm{K}$ and $\mathrm{N}$ fertilization.

\subsection{Fruit Yield and Orchard Profit}

The litchi yields with $\mathrm{K}_{0.6} \mathrm{~N}, \mathrm{~K}_{0.8} \mathrm{~N}, \mathrm{~K}_{1.0} \mathrm{~N}, \mathrm{~K}_{1.2} \mathrm{~N}$, and $\mathrm{K}_{1.4} \mathrm{~N}$ treatments in 2010 were $7.77,9.38,10.80$, 9.71, and $9.60 \mathrm{t} \mathrm{ha}^{-1}$, respectively, with an increase of $20.7 \%, 39.0 \%, 25.0 \%$, and $23.6 \%$ compared with that of the $\mathrm{K}_{06} \mathrm{~N}$ treatment. In 2011, the litchi yields were 9.59, 9.99, 10.88, 12.63, and $11.19 \mathrm{t}$ $\mathrm{ha}^{-1}$, with an increase of $4.2 \%, 13.5 \%, 31.7 \%$, and $16.7 \%$, respectively, compared with that of the $\mathrm{K}_{0.6} \mathrm{~N}$ treatment. The litchi yields in 2012 were 3.36, 3.95, $4.34,6.03$, and $4.37 \mathrm{t} \mathrm{ha}^{-1}$, with an increase of $17.6 \%$, $29.2 \%, 79.5 \%$, and $30.1 \%$, respectively, compared with that of the $\mathrm{K}_{0.6} \mathrm{~N}$ treatment. The average yield of litchi in three years were 6.91, 7.77, 8.67, 9.46, and $8.39 \mathrm{t} \mathrm{ha}^{-1}$, with an increase of $12.5 \%, 25.6 \%, 26.9 \%$, and $21.4 \%$, respectively, compared with that of the $\mathrm{K}_{0.6} \mathrm{~N}$ treatment. With increasing $\mathrm{K}_{2} \mathrm{O} / \mathrm{N}$ ratio, the litchi yield initially increases and then subsequently decreases. By comparing the $\mathrm{K}_{2} \mathrm{O} / \mathrm{N}$ ratio and litchi yield (Figure 4), we determined that $\mathrm{K}_{2} \mathrm{O} / \mathrm{N}$ is 1.16 when the yield is at maximum. Yield and weight data from 2012 show that the litchi fruit yield and weight per fruit have a positive correlation and are nearly the same with significant level $(r=0.7869$, 
$P=0.0516$ ). Therefore, improving the $\mathrm{K}_{2} \mathrm{O} / \mathrm{N}$ ratio can increase the litchi yield as this improvement promotes fruit expansion and single fruit weight. Overall, the litchi fruit yield from the 2012 experiment was low and closely related with the practice of ringing the branches a week before pre-flowering to preserve the fruits. Late ringing causes very low fruit setting rate, thus resulting in low overall production for the year. The orchard profits with $\mathrm{K}_{0.6} \mathrm{~N}, \mathrm{~K}_{0.8} \mathrm{~N}, \mathrm{~K}_{1.0} \mathrm{~N}, \mathrm{~K}_{1.2} \mathrm{~N}$, and $\mathrm{K}_{1.4} \mathrm{~N}$ treatments in 2010 were $5739,7683,9417$, 8025 , and 7857 US\$ per hectare, with an increase of $33.9 \%, 64.1 \%, 39.8 \%$, and $36.9 \%$, respectively, compared with that of the $\mathrm{K}_{0.6} \mathrm{~N}$ treatment. In 2011, the orchard profits were 7793, 8252, 9261, 11305, and 9586 US\$ per hectare, with an increase of $5.9 \%$, $18.8 \%, 45.1 \%$, and $23.0 \%$, respectively, compared

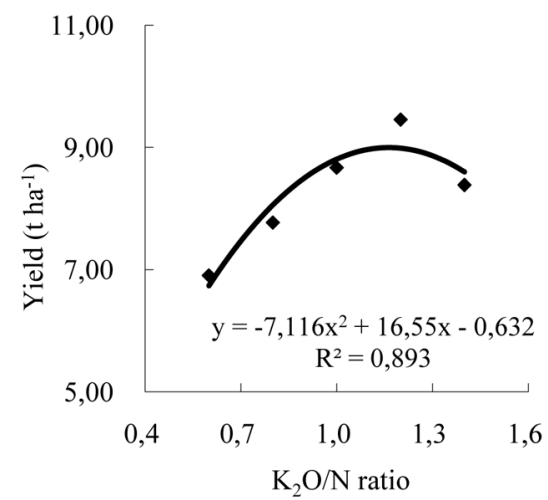

with that of the $\mathrm{K}_{0.6} \mathrm{~N}$ treatment. The orchard profits in 2012 were 2237, 3273, 3925, 6933, and 3910 US\$ per hectare, with an increase of $46.3 \%, 75.4 \%$, $209.9 \%$, and $74.8 \%$, respectively, compared with that of the $\mathrm{K}_{0.6} \mathrm{~N}$ treatment. The average orchard profits in three years were 5256, 6402, 7534, 8754, and 7117 US\$ per hectare, with an increase of $21.8 \%, 43.3 \%$, $66.5 \%$, and $35.4 \%$, respectively, compared with that of the $\mathrm{K}_{0.6} \mathrm{~N}$ treatment. With increasing $\mathrm{K}_{2} \mathrm{O} / \mathrm{N}$ ratio, the orchard profit initially increases and then subsequently decreases. By comparing the $\mathrm{K}_{2} \mathrm{O} / \mathrm{N}$ ratio and orchard profit (Figure 4), we determined that $\mathrm{K}_{2} \mathrm{O} / \mathrm{N}$ is 1.16 when profit is at maximum.

Consequently, the proper application of $\mathrm{K}$ and $\mathrm{N}$ fertilizer can considerably increase the fruit yield and the litchi plantation profit.

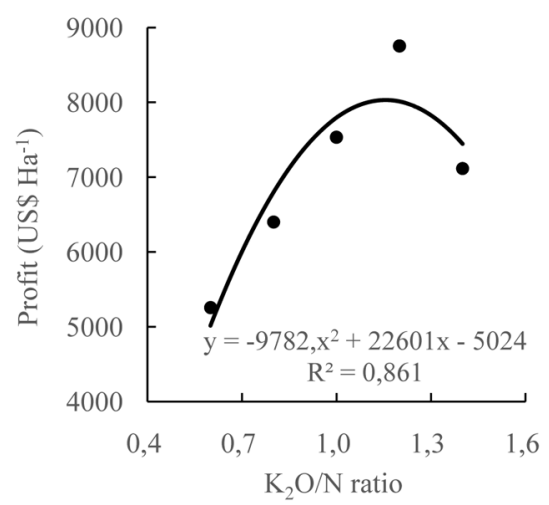

Figure 4. Relationship between $\mathrm{K}_{2} \mathrm{O} / \mathrm{N}$ ratio and litchi fruit yield and orchard profit

\subsection{Analysis of average litchi yield and cumulative litchi yield difference}

Comparison of the resulting stabilities with the different fertilizer treatments (Table 3) shows that the yield stabilities varied with different $\mathrm{N} / \mathrm{K}$ ratios. With the same $\mathrm{N}$ content, the litchi yield stability coefficient initially increases and then subsequently decreases with increasing $\mathrm{K}_{2} \mathrm{O} / \mathrm{N}$ ratio. By contrast, the yield coefficient initially decreases then subsequently increases. Stability with the $\mathrm{K}_{1.2} \mathrm{~N}$ treatment was the highest, followed by the $\mathrm{K}_{1.0} \mathrm{~N}$ treatment, whereas the stability with $\mathrm{K}_{0.6} \mathrm{~N}$ treatment was the lowest. These results indicated that litchi orchard soil ecosystems with $\mathrm{K}_{1.2} \mathrm{~N}$ treatment may be more stable, thus improving 
the soil nutrients to the support capacity and system stability of the litchi orchard soil ecology.

\subsection{Fruit Harvest time}

The harvest rate of litchi fruit at the maturation stage in 2010 to 2012 was recorded and is illustrated in Figure 5. In this study, the fruit harvest rate decreased with increasing $\mathrm{K}_{2} \mathrm{O} / \mathrm{N}$ ratio. The litchi with low $\mathrm{K}_{2} \mathrm{O} / \mathrm{N}$ matured earlier, whereas that with high
$\mathrm{K}_{2} \mathrm{O} / \mathrm{N}$ ratio matured later. Moreover, this observation became more significant with the extension of the test time. As a result, during litchi production, proper application of $\mathrm{K}$ and $\mathrm{N}$ fertilizer was beneficial to the fruit harvest. Applying more $\mathrm{K}$ fertilizer will result in a delayed harvest time. Thus, a relatively low $\mathrm{K}_{2} \mathrm{O} / \mathrm{N}$ ratio will result in a satisfactory purchasing price in the early litchi production regions, and a relatively high $\mathrm{K}_{2} \mathrm{O} / \mathrm{N}$ ratio could be adopted to postpone the fruit harvest in the late litchi production regions.
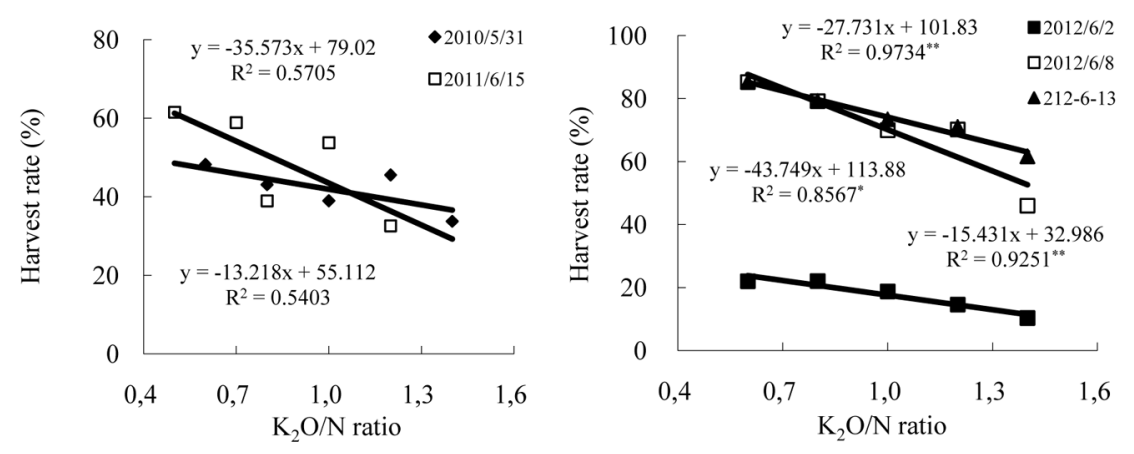

Figure 5. Relationship between $\mathrm{K}_{2} \mathrm{O} / \mathrm{N}$ ratio and litchi fruit harvest rate

Notes: Values with * are significantly different by the CORR Test $(\mathrm{P}<0.05)$, and values with ** are significantly different by the CORR Test $(\mathrm{P}<0.01)$.

\section{Discussion and Conclusions}

$\mathrm{K}$ is the most abundant cationic mineral in the fruit tree body and is present in the cytoplasm and vacuole as an ion. Moreover, this ion is closely related to the growth of the fruit tree. In contrast to the other nutrient minerals, $\mathrm{K}$ is absent in the metabolite composition of fruit trees, but is an essential element. $\mathrm{K}$ is an activator of numerous enzymes and is involved in the synthesis of sugar and starch, as well as in their transportation and transformation ( $\mathrm{Tu}$ et al., 2009). Previous studies have indicated that $\mathrm{K}$ can enhance litchi leaf photosynthesis and nutrient accumulation, which are necessary for the following year's production (Deng et al., 1993; Deng, et al., 1994). The results of this study showed that throughout the growth period, the leaf $\mathrm{K}$ content of litchi after fruit picking decreased to a minimum level, in which adequate $\mathrm{K}$ fertilizer (30\% is appropriate) should be applied after picking to restore and

the following year. Goldchmidt et al. (1982) stated that the fruit setting and development require a large amount of energy, which may also be limited to the available carbohydrates. Deng et al. (1993) reported that the demand for carbohydrates during litchi flowering and fruit development is evident. The lack of carbohydrates in the mid- and late-fruit development is closely related to the second physiological fruit 
drop, which has become the main factor affecting production (Deng et al., 1993). The present study showed that in the flower bud differentiation period to the early fruit enlargement period, the leaf $\mathrm{K}$ content rapidly decreased, and the leaves gradually completed the transition from functioning as a "library" to as a "source" and then shifted toward the reproduction and growth centers. This transition is the critical moment for $\mathrm{K}$ absorption. Therefore, a small amount of pre-flowering $\mathrm{K}$ fertilizer ( $10 \%$ is appropriate) and an appropriate flowering and fruit-promoting $\mathrm{K}$ fertilizer (20\% is appropriate) must be applied to meet the needs of litchi for flower bud differentiation, flowering induction, and fruit setting. In addition, fruit-strengthening potassium fertilizer $\quad(40 \%$ appropriately) should also be adopted during the fruit enlargement period to promote litchi fruit expansion and to improve litchi yield and quality.

$\mathrm{K}$ has a significant role in fruit development, yield, and quality, as well as in stress and disease resistance and other aspects (Saykhul et al., 2014; Yurtseven et al., 2005). Studies show that the lack of $\mathrm{K}$ results in the improper development of the organizational structure of vegetative organs. For instance, the photophosphorylation and electron transfer capacity of chloroplasts significantly decreases; carbon assimilation is hindered; and root oxidant activity and yield decrease (Yu et al., 1996). However, the addition of K fertilizer may extend the functional period of leaves, thus improving the photosynthetic rate and stimulating the crops (Zheng et al., 2002). $\mathrm{K}$ is also an essential nutrient for plant carbohydrate synthesis, transfer, conversion, and storage and also has a role in inhibiting $\mathrm{N}$ absorption and adjusting its excessive growth. The results show that with the same $\mathrm{N}$ content, the litchi yield and plantation profit increase and then decrease as the $\mathrm{K}_{2} \mathrm{O} / \mathrm{N}$ ratio improves. When $\mathrm{K}_{2} \mathrm{O} / \mathrm{N}$ was 1.16 , the three-year fruit yield and profit reach their maximum values. Southern China is the main production area for litchi. Dark respiration is predominant during litchi flowering and fruit setting periods in the spring and summer seasons because these periods are in the plum rainy times with short light duration and little photosynthesis. However, the tree metabolic functions can be improved, and ineffective respiration can be reduced by using an appropriate $\mathrm{K}$ fertilizer, which is essential for the improvement of the tree's carbohydrate supply and accumulation level as well as for fruit setting and yield (Deng et al., 1994). Therefore, on the basis of the different soil conditions in the main litchi production area and annual yields in China, including the yield response to fertilizer with a certain $\mathrm{K} / \mathrm{N}$ ratio, we recommend that the $\mathrm{K}_{2} \mathrm{O} / \mathrm{N}$ ratio for nutrient supplementation to be at 1.0 to 1.2 .

\section{Acknowledgements}

This work was financially supported by the earmarked fund for Modern Agro-industry Technology Research System (CARS-33) from Ministry of Agriculture of P.R. China.

\section{References}

Agbangba, E.C., Sossa, E.L., Dagbenonbakin, G.D., Diatta, S., Akpo, L.E 2011. DRIS model parameterization to access pineapple variety 'Smooth Cayenne' nutrient status in Benin ( West Africa) Journal of Asian Scientific Research. 1(5), 254-264.

Bussi, C., Besset ,J., Girard, T. 2003. Effects of fertilizer rates and dates of application on apricot (cv Bergeron) cropping and pitburn. Scientia Horticulturae. 98(2), 139-147.

Deng, Y.C., Ni, Y.Y., Chen, N.R. 1993. Effects of Potassium on Photosynthetic Characteristics Carbohydrate Accumulation and Fruit-set in Litchi. Journal of South China Agricultural University. 14(2), 91-95. 
Deng, Y. C., Ni, Y. Y. Chen, N.R. 1994. Studies on the effects of Potassium on Photosynthesis and Respiration of Litchi. Journal of South China Agricultural University. 15(4), 80-84.

Egea, L., Leon, A., Carpena, O. 1972. Nutrition minérale chez certains Prunus L. Influence del'espece. Fruits. (27), 287-291.

Goldschmidt, E.E., Golomb, A. 1982. The carbohydoate balance of alterate-beering citrus trees and the significance of flowering and fruiting. Journal of the American Society for Horticultural Science. 107(2), 206-208.

He, Z.L., Calvert, D.V., Alva, A.K., Banks, D.J., Li, Y.C. 2003. Thresholds of leaf nitrogen for optimum fruit production and quality in grapefruit. Soil science society of American Journal. 67(2), 583-588.

Hu, B,M., Geng, X. 1993. Methods for crop stability analysis. Science Press, Beijing.

Jiang, W.F., Cui, Y.F., Zhang, W.D., Chen, J., Fan, W.J., Yu, X.D., Zhou, J.B. 2005. Annual changes of mineral elements in foliar of Thompsons seedless. Journal Northwest A \& F University . 33(8), 92-95.

Li, G.L., Yao, L.X., Zhang, Z.Q., He, Z.H., Zhou, C.M., Huang, L.X., Guo, B., Tu, S.H. 2011. Temporal and Spatial Variation of Nutrient Fertility on Guangdong Litchi Plantation. Chinese Journal of Soil Science. 42(5), 1081-1086.

Li, X., Zhang, L. J., Liu. W. S., Yang, H.M., Ma, Z.Y. 2007. On Nutrient Accumulation and Distribution in Plum Tree as well as Nutrient Dynamic Changes in Plum leaves. Soils. 39(6), 982-986.

Lu, R. K. 2000. Analysis method in soil agricultural chemistry. China Agricultural Scientech Press, Beijing.

Men, M. X., Li, X. W., Xu, H. 2008. Effects of LongTerm Fertilization on Crop Yields and Stability. Scientia Agricultura Sinica. 41(8), 2339-2346.
Menzel, C.M., Carseldine, M.L., Haydon, G.F., Simpson, D.R. 1992. A review of existing and proposed new leaf nutrient standards for |lychee. Scientia Horticulturae. 49, 33-53.

Menzel, C.M., Simpson, D.R. 1987. Lychee Nutrition: A Review. Scientia Horticulturae. 31, 195-224.

Nachtigall, G.R. Dechen, A.R 2007. DRIS norms for evaluating the nutritional state of apple tree Scientia Agricola. 64(3), 282-287.

Raghupathi, H.B., Reddy, Y.T.N., Reju, M.K., Bhargava, B.S 2005. Diagnosis of nutrient imbalance in mango by DRIS and PCA approaches Journal of Plant Nutrition. 27(7), 1131-1148.

Reyes, R.A. 2000. Effect of mineral nutrition on bud flower drop of apricot 17-10 selection. Terra. 18(4), 299-304.

Saykhul, A., Chatzissavvidis, C., Therios, I., Dimassi, K., Chatzistathis, T. 2014. Growth and nutrient status of olive plants as influenced by foliar potassium applications. Journal of soil science and plant nutrition. 14(3):602-615.

Sharma, K.L., Mandal, U.L., Srinivas, K., Vittal, K.P.R., Mandal, B., Grace, J.K., Ramesh, V. 2005. Long-term soil management effects on crop yields and soil quality in a dryland Alfisol. Soil and Tillage Research. 83(2), 246-259.

Torres, P.L., Aular, J. 2010. Rengel, M., Montano, J. Nutritional diagnosis of orange orchards in Yaracuy State by using the modified DRIS ( DRIS-M). Bioagro. 22(2), 127-134.

Tu, M.Y., Jiang, G.L., Du, J.C., Liao, M.A., Chen, D. 2009. Effect of Potassium on the Tree Nutrient Status in Fruit Picking Period of Nectarine. Northern Horticulture. 12, 29-33.

Xu, Y.J., Wen, J., Xiao, G.S., Zhang, M.W., Li, S.F., Wu, J.J. 2010. Comparative studies of processing characteristics of different litchi varieties. Food Science. 31(1), 33-37. 
Yao, L.X. 2009. Investigation report on the application and demand of national litchi nutrient management technology. Litchi Science Technology Communications. 3, 41-54.

Yao, L.X., Li, G.L., Yang, B.M., He, Z.H., Zhou, C.M., Huang, L.X., Guo, B. 2009. Nutrient accumulation properties of Guiwei and Feizixiao litchi. Litchi Science Technology Communications. 2, 52-64.

Yurtseven, E., Kesmez, G.D., Ünlükara, A. 2005. The effects of water salinity and potassium levels on yield, fruit quality and water consumption of a native central anatolian tomato species (Lycopersicon esculantum) . Agricultural Water Management. 78, 128-135.

Yu, Z.W., Zhang, W., Yue, S. S., Shen, C.G., Yu, S.L. 1996. Effect of potassium on photosynthesis and senescence in winter wheat. Acta Agronomica Sinica. 22(3), 305-312.
Zeng, Y.J., Gao, Y.M., Tong, Y.A. 2011. Effect of N supply on the developments of $\mathrm{N}$ in leaves and new branches in "Fuji" apple. Journal Northwest A\&F University. 39(2), 198-201.

Zhang, T.T., Xu, F.L., Wang, Y.K., Lin, Y. 2012. Effects of fertilization on growth and seasonal dynamic of leaf nutrients of close planting pearjujube trees. Journal of Plant Nutrition and Fertilizer. 18(1), 241-248.

Zheng, B.S., Cheng, X.J., Jiang, D.A., Weng, X.Y. 2002. Effect of potassium on photosynthesis, Rubisco and RCA in plant. Journal of Zhe-jiang Forestry College. 19(1), 104-108.

Zhou, K. B., Guo, W. W., Xia, R, X., Wang, G.Y., Shen, T. 2004. Effects of two kinds of rootstock on growth and change of nutrient contents in leaf of young tree of navel orange. Journal of Plant Nutrition and Fertilizer. 10(6), 657-662. 